\title{
Új lágy gyógyszerek kifejlesztése és klinikai sikere*
}

\author{
Bodor Miklós dr.
}

University of Florida, Miami, Amerikai Egyesült Államok

\begin{abstract}
A retrometabolikus gyógyszertervezés összekapcsolja a szerkezet-hatás és szerkezet-metabolizmus összefüggéseket, így sikeresen választja el a kívánt hatást és a mellékhatásokat. Ez a terápiás index lényeges javulását eredményezi. A fó szempont, hogy ne csak tanulmányozzuk a metabolizmust, hanem a gyógyító hatás mellett egy kívánt metabolizmust tervezzünk be a gyógyszermolekulába. Két általános, különálló tervezési módszer alkalmazható, melyek a gyógyszer irányítását ellentétes módon végzik. Viszont, mind a 1) kémiai gyógyszerirányító rendszerek (CDS), mind a 2) lágy gyógyszerek a megtervezett metabolizmust használják a gyógyszer hatásának és irányításának szabályozására. A lágy gyógyszerek tervezésekor a hidrolitikus enzimekre kell támaszkodni, az oxidatív folyamatok szigorúan kerülendők. A jelen munkában elsősorban az általunk megtervezett lágy gyógyszerek sikeres klinikai használatára irányítjuk a figyelmet. Csak hogy érzékeltessük a különbséget, először az agyba irányított kémiai rendszert mutattuk be, ahol a kiinduló inaktív molekula szekvenciális metabolizmusa az agyba koncentrálja a hatóanyagot. A lágy gyógyszerek közül a nagyon sikeres lágy kortikoszteroidokat mutatjuk be először, világszerte használják a loteprednol-etabonátot már több mint 20 éve, s alkalmazása egyre nő. A kortikoszteroid-terápiás index drámai javulása mellett a tipikus, általános és súlyos szemészeti mellékhatásokat, a belső szemnyomás emelése révén a glaukóma és a katarakta kialakulását sikerült kiküszöbölni. Hasonlóképpen tervezett második generációs lágy kortikoszteroidokat is bemutatunk, ahol a farmakofor kialakítása szerkezetileg meglepő módon történt. Az egyik legújabb sikeres lágy gyógyszer a sofpironium bromide, egy lágy antikolinerg, többrétû́ klinikai felhasználhatósága közül a hyperhidrosis, egy kielégítetlen szükséglet kezelésére lett először kifejlesztve. A sikeresen befejezett III. klinikai fázis után rövidesen piacra kerül. A jól meghatározott tervezési szabályok lehetővé tették a lágygyógyszer-tervezés számítógépes szakértői rendszerének kifejlesztését is.
\end{abstract}

Orv Hetil. 2020; 161(10): 363-373.

Kulcsszavak: gyógyszertervezés, terápiás index, metabolizmus, agyba irányítás, kortikoszteroidok, szemészet, gyulladás, allergiák, szürke hályog, acetil-kolin, antikolinerg, hyperhidrosis, sclerosis multiplex, szakértői rendszer

\section{Development and clinical success of novel soft drugs}

Retrometabolic drug design combines the structure-activity and structure-metabolism relationships, allowing the effective separation of drug action and side effects. This combination results in significant improvement of the therapeutic index. The main aim is not only to study the metabolism but to build into the drug molecule the desired metabolic route, in addition to the therapeutic activity. There are two basically different approaches to achieve this aim. Both use designed-in metabolism. The 1. chemical drug-targeting systems (CDS) and 2. soft drug, both control the drug targeting and action by strategically designed metabolism. In the case of the soft drugs, we want to rely on hydrolytic enzymes, avoiding the oxidative processes. In the present work, we focus on the clinical successes of the soft drugs designed in our laboratories. In order to show the difference, we briefly present a brain-targeted delivery system, where the originally inactive molecular construct undergoes sequential metabolism to allow specific concentration of the active drug in the brain. Among the soft drugs first we present the highly successful soft corticosteroids. Loteprednol etabonate has been used worldwide for over twenty years, and its use is constantly growing. In addition to the dramatically improved therapeutic index, the specific, serious ophthalmic side effects (elevation of intraocular pressure; glaucoma and cataract formation) were completely eliminated. Similarly designed second generation of soft corticosteroids are also presented, where the soft pharmacophore is structurally unexpected. The most recent soft drug design involves anticholinergics. Sofpironium bromide, a highly effective molecule but without the typical an-

\footnotetext{
*A Szerkesztőség felkérésére készített tanulmány, amely a Szerzőnek a Szabó Sándor (Irvine, CA) és Vécsei László (Szeged) professzorok által „Innovatív Medicina. Új gyógyszerjelölt molekulák és orvosi múszerek. Magyar kutatók és feltalálók” címmel a Magyar Tudományos Akadémián 2019. május 10-én rendezett szimpóziumon elhangzott előadása alapján készült.
} 
ticholinergic side effects, was first developed to treat hyperhidrosis, an unmet need. Phase III clinical studies were successfully completed and its marketing approval is pending. Since the soft drug design principles, methods and rules are general and specific in nature, a computerized expert system was also developed.

Keywords: drug design, therapeutic index, drug metabolism, brain targeting, corticosteroids, ophthalmic drugs, inflammation, allergies, glaucoma, acetylcholine, anticholinergic, hyperhidrosis, multiple sclerosis, expert system

Bodor M. [Development and clinical success of novel soft drugs]. Orv Hetil. 2020; 161(10): 363-373.

(Beérkezett: 2019. október 7.; elfogadva: 2019. november 20.)

\begin{abstract}
Rövidítések
$\mathrm{AK}=$ acetil-kolin; $\mathrm{ANK}=$ acetil-norkolin; $\mathrm{BV}=$ betametazon$17 \alpha$-valerát; $\mathrm{CA}=\Delta \mathrm{l}$-kortiensav; $\mathrm{CBG}=($ corticosteroid-binding globulin) kortikoszteroid-kötő globulin; CDS $=($ chemical drug-targeting system) kémiai gyógyszerirányító rendszer; $\mathrm{COPD}=$ (chronic obstructive pulmonary disease $)$ krónikus obstruktív tüdőbetegség; ED = etiprednol-dikloacetát; FDA = (U. S. Food and Drug Administration) az Amerikai Egyesült Államok Élelmiszer-biztonsági és Gyógyszerészeti Hivatala; GR = glükokortikoid-receptor; GYKI = Gyógyszerkutató Intézet; $\mathrm{HB}=$ hidrokortizon-17 $\alpha$-butirát; $\mathrm{HDL}=$ (high-density lipoprotein) magas sürüségü lipoprotein; IOP $=$ (intraocular pressure) szemnyomás; $\mathrm{KP}=$ klobetazol-17 $\alpha$-propionát; LASIK = (laser-assisted in situ keratomileusis) lézerasszisztált in situ keratomileusis; LE = loteprednol-etabonát; NAD = nikotinamid-adenin-dinukleotid; NADH = nikotinamid-adenin-dinukleotid-hidrát; SAR $=$ (structure-activity relationship $)$ szerkezet-hatás összefüggés; $\mathrm{SD}=$ (soft drug) lágy gyógyszer; $\mathrm{SMR}=$ (structure-metabolism relationship) szerkezet-metabolizmus összefüggés; $\mathrm{TD}$ = toxikus dózis; $\mathrm{TI}$ = terápiás index; USAN $=$ United States Adopted Names Bizottság
\end{abstract}

A gyógyszertervezés és -fejlesztés folyamata igen összetett, számos tudományágat és technikai területet foglal magában. A klasszikus gyógyszertervezés a meghatározott szerkezetú és kívánatos biológiai hatással rendelkező vegyület kiválasztásával kezdődik. E molekula szerkezeti családját vizsgáljuk a következőkben, szerkezet-hatás összefüggést (structure-activity relationship, SAR) keresve. A cél, hogy azonosítsuk a leghatékonyabb molekulát, s ezt lehetóleg gyógyszerré fejlesszük ki. Sajnos a dolog nem ilyen egyszerú, nagyon gyakran ezt az ígéretes hatásos vegyületet a fejlesztés valamelyik későbbi szakaszában egy előre nem látott toxicitás, nemkívánatos mellékhatás miatt el kell vetni. Ennek egyik lehetséges oka, hogy a célreceptor mindenütt jelen van a testben, így a mellékhatások kialakulása szinte elkerülhetetlen. Másrészt a legtöbb gyógyszer a metabolizmusa során különböző hatású, gyakran toxikus metabolitokra bomlik. Sok egyéb követelménynek kell teljesülnie, hogy a molekula ténylegesen gyógyszerré váljon. Így a preklinikai kiválasztás során fejlesztésre kerülő 5000 molekulából csak egy kerül piacra (bár ez sem jelenti a végső sikert), és átlagosan 12-15 évbe és 2-2,5 milliárd dollárba kerül a bevezetése.
Arra a következtetésre jutottunk, hogy a gyógyszertervezés elsődleges célja nem a hatásmaximalizálás, hanem a terápiás index (TI) javítása, jelentôs növelése kell, hogy legyen. A TI-t a toxikus dózis (TD50) és az effektív dózis hányadosaként értelmezzük:

$$
\mathrm{TI}=\mathrm{TD} 50 / \mathrm{ED} 50
$$

Tehát a TI a szelektivitás mértékét, a gyógyszer hatásának és toxicitásának szétválaszthatóságát tükrözi.

A szervezetbe bevitt idegen anyag (mely a jelen esetben egy gyógyszermolekula - D) metabolizmusa során rendszerint nagyon sok metabolitrokon vegyület képződik, elsősorban közeli analóg metabolitok $\left(\mathrm{D}_{1} \ldots \mathrm{Dm}\right)$, amelyek szerkezete és hatása hasonló az eredeti (D) molekuláéhoz, de farmakokinetikai jellemzőik eltérőek, illetve egyéb metabolitok $\left(M_{1} \ldots \mathrm{Mg}\right)$, beleértve a hatástalan, inaktív metabolitokat (Mi...Mj), ezenkívül a nemkívánatos reaktív oxidációs közti termékek $\left(\mathrm{I}^{*} \mathrm{k} . . . \mathrm{I}^{*} \mathrm{~m}\right)$, amelyek sejtkárosodást okoznak.

\section{A retrometabolikus gyógyszertervezés}

A fentiekből világosan látszik, hogy a metabolizmussal kapcsolatos megfontolások a gyógyszertervezés fontos részét kell, hogy képezzék. A retrometabolikus gyógyszertervezés új, általános módszertani eljárásokat biztosít, a szerkezet-hatás (SAR) és a szerkezet-metabolizmus (SMR) összefüggéseinek összekapcsolása révén [1]. Ez a kapcsolat lehetóvé teszi lényegesen biztonságosabb, nem toxikus gyógyszerek tervezését, amelyek a kívánt optimális gyógyító hatás megvalósulása után, a szerkezetileg a molekulába beépített metabolizmus eredményeként gyorsan lebomlanak, elkerülve a mellékhatásokat (1. ábra).

$\mathrm{Az}$ 1. ábrán bemutatjuk a retrometabolikus kettôs hurkot, amely magában foglalja a két általános, hatást és metabolizmust összekapcsoló módszert. Az egyik, a kémiai irányító rendszer (CDS) esetében a hatóanyagot (D) „eldugjuk” egy hatástalan inaktív szerkezetbe, melyben különböző szerkezeti részeknek különböző feladatuk van; a megtervezett metabolizmus lépésenként változtatja az anyag eloszlását és fizikai tulajdonságát, a célszervbe irányítja, feldúsítja a hatóanyagot. Errôl többször, részletesebben írtunk [2], elsősorban a szelektív, agyba [3-6] irányított gyógyszerekkel kapcsolatban, 


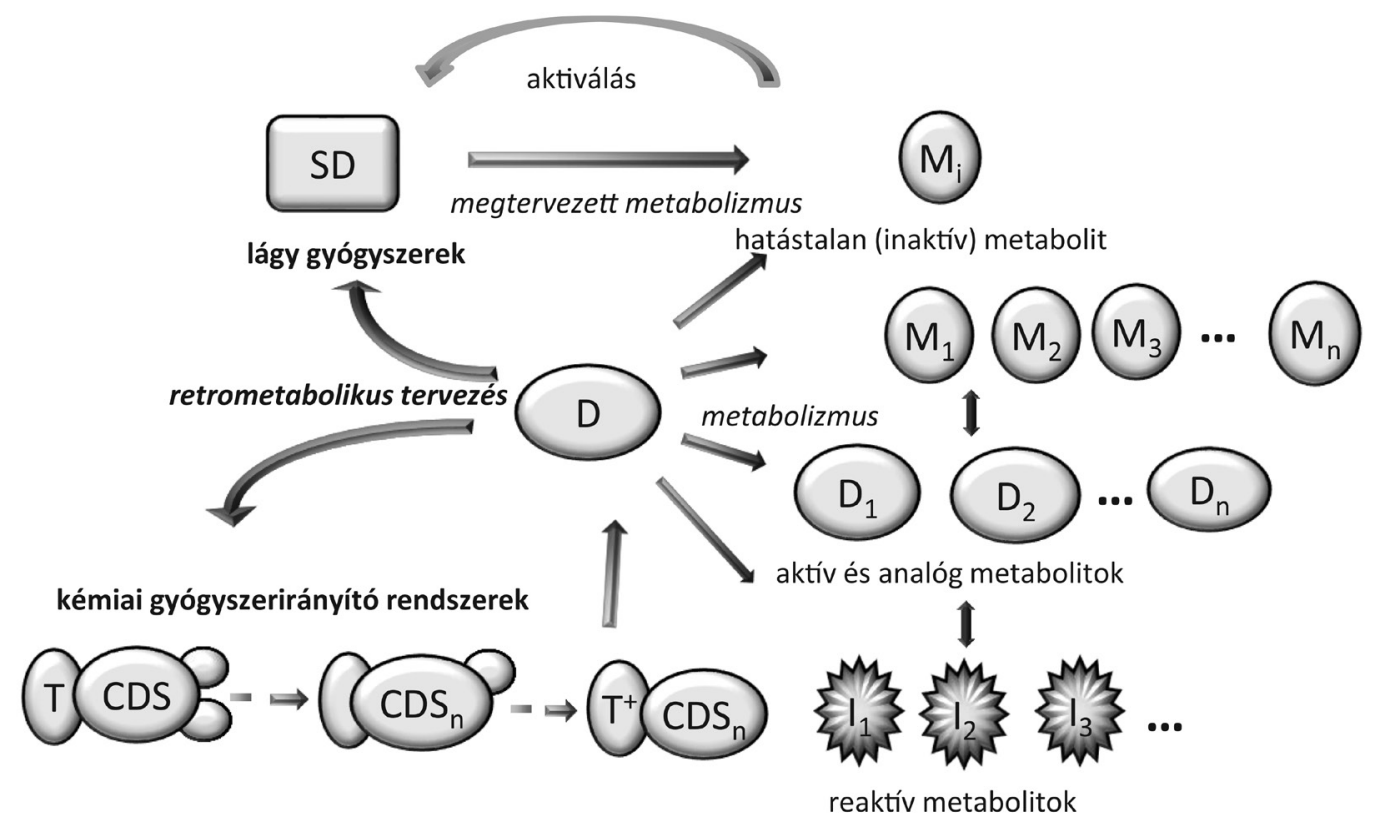

1. ábra

\begin{abstract}
A retrometabolikus kettős hurok. Kémiai gyógyszerirányító rendszerek (bal oldal) és lágy gyógyszerek (jobb oldal). A görbe nyilak a retrometabolikus tervezésmódokat, az egyenes nyilak a metabolizmus okozta változásokat jelképezik. $\mathrm{D}$ az aktív gyógyszer, $\mathrm{D}_{1} \ldots \mathrm{Dn}_{\mathrm{az}}$ analóg metabolitok, $\mathrm{M}_{1} \ldots \mathrm{Mn}_{\mathrm{n}}$ az egyéb metabolitok, Mi a hatástalan metabolit(ok) és $I^{*}, I^{*} \ldots I^{*} n$ a reaktív közti termékek. A CDS az inaktív első szerkezetben (T-T+) az irányító rész. A szekvenciális metabolizmus a D-hatóanyagot kibocsátja a célszervben. A lágygyógyszer-tervezés egy hatástalan metabolitból indul ki, azt kémiai változtatásokkal egy, a D-hez hasonló lágy SD-vé alakítjuk, amely egy betervezett metabolizmussal visszaalakul a kiinduló inaktív metabolittá

$\mathrm{CDS}$ = kémiai gyógyszerirányító rendszer; $\mathrm{SD}$ = lágy gyógyszer
\end{abstract}

amit a 2. ábrán láthatunk. Ez nagyon röviden az agyspecifikus gyógyszerirányító rendszert mutatja be, ahol az aktív D-molekula egy lipofilikus hatástalan szerkezetben - T-D-F - van „eldugva”, ez könnyen áthatol a vér-agy gáton. A szerkezet fontos része a $\mathrm{T}$ irányító funkció, (a NADH $\leftrightarrow \mathrm{NAD}^{+}$koenzimpárhoz hasonló redox rendszer), amely egy enzimatikus reakció során egy pozitív töltésre tesz szert, így a $\mathrm{T}^{+}-\mathrm{D}-\mathrm{F}$ nem tud a vér-agy gáton visszajönni, ugyanis az ionizált molekulák számára a membránok nem járhatók át, s egyéb betervezett metabolikus folyamatok specifikusan az agyban lebontják az aktív D-re. A periférián létrejött $\mathrm{T}^{+} \mathrm{D}-\mathrm{F}$ gyorsan kiürül,

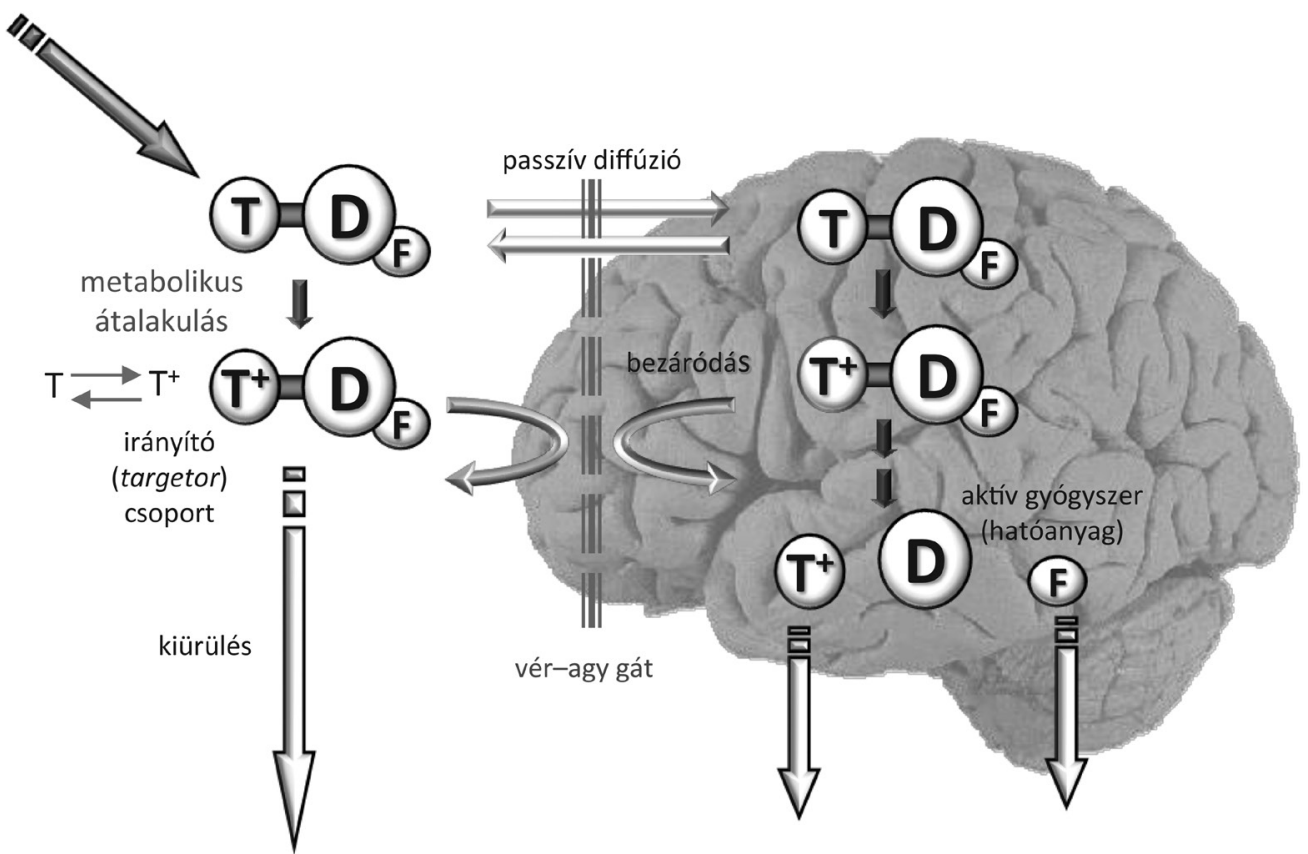


mielőtt aktiválódna. Sikeres klinikai vizsgálatokat és terápiás lehetőségeket írtak le az agyba irányított ösztradiol esetében [7] (2. ábra).

\section{A „lágy gyógyszerek” (SD-k) tervezési módszere}

A lágy gyógyszerek új terápiás hatással rendelkező anyagok, amelyek szerkezetébe a kívánt hatás mellett a metabolikus hatástalanítás útja is be van építve. Ezek tehát olyan új gyógyszerek, amelyek fó tulajdonsága az, hogy terápiás feladatuk elvégzése után a betervezett metabolizmus felhasználásával a kívánt sebességgel hatástalan molekulává bomlanak le. Lágy gyógyszerek tervezésekor nem a metabolizmus elkerülése a cél, hanem annak ellenőrzött irányítása. Ez úgy érhető el, hogy egy specifikus, metabolizmusra érzékeny szerkezeti részt építünk be a molekulába. Fontos hangsúlyozni, hogy ez a betervezett metabolizmus elsősorban hidrolízis, tehát észterázok által közvetített hatástalanítás, hogy elkerüljük az oxidációs folyamatokat. Ez azért fontos, mert az oxidációs folyamatok (például a citokróm-P450-függő) sokszor reaktív, toxikus közti termékeket eredményeznek, másrészt tekintve, hogy az oxidációs metabolizmus lassú, könnyen telíthető, és a más oxidálható molekulákkal való verseny (gyógyszer-gyógyszer kölcsönhatás) további problémákat okoz.

Tehát a lágy gyógyszer előnyei:

1. A gyógyszer hatás- és eloszlásprofiljának leegyszerúsítése (a reaktív termékek képződésének elkerülésével).

2. A gyógyszer-gyógyszer kölcsönhatás kiküszöbölése, a telíthető vagy túlterhelt enzimrendszerekért versenyző metabolizmus elkerülésével.

3. A szisztémás és a távoli toxicitás elkerülése (a megtervezett, gyors metabolizmus eredménye).

4. A jelentősen (gyakran drámaian) javuló terápiás index (a reaktív, toxikus közti termékek elkerülése és a nemkívánatos, szisztémás mellékhatások hiánya vagy csökkentése).

A lágy gyógyszer fogalmát 1976-ban vezették be [8], majd kiteljesítése és részletezése 1980-ban történt meg [9-11]. Az alkalmazott tervezési módszer alapján négy osztályba sorolhatjuk ezeket az új, különleges aktív molekulákat [9]. E tervezési módszerek közül kettő, a „lágy analógok” és az „inaktív metabolit” módszere bizonyult a legsikeresebbnek.

Mint már előzőleg említettük, a lágy gyógyszer tervezésében nem a metabolizmus elkerülése a cél, hanem annak tudatos irányítása és ellenőrzése. A molekula aktivitását a farmakoforok (farmakofor: egy gyógyszermolekula szterikus és elektronikus jellemzőinek absztrakt kombinációja, amely biztosítja az optimális szupramolekuláris kölcsönhatást egy kiválasztott makromolekuláris biológiai célponttal) jelenléte biztosítja, de egy másik fontos szerkezeti elem a kívánatos metabolizmusra érzékeny csoport („lágy”), amely a megtervezett metabolizmusért felelős. A cél, hogy a hatástalanítás egyetlen, kis energiájú lépés legyen, s a hatástalan termékek gyorsan kiürüljenek. Hogy elkerüljük a nemkívánatos oxidatív metabolizmusokat, az oxidációs reakciókat kémiailag előre elvégezzük, így a reaktivált, lágy gyógyszer tervezése egy oxidált metabolitból indul ki. Ez a folyamat könnyebben megérthetô majd a példákból. A szervezetben mindenütt jelen lévő észterázokat használjuk.

A lágygyógyszer-tervezés bevezetése óta eltelt időben nagyon sok sikeres alkalmazás található a szakirodalomban, és - fóleg újabban - egyre több így tervezett, biztonságosabb gyógyszer került forgalomba [12]. A jelen közleményben elsősorban a saját laboratóriumunkban kifejlesztett lágy gyógyszerek klinikai sikerességére koncentrálunk.

\section{Lágy kortikoszteroidok}

A hagyományos kortikoszteroidok nagyon hasznos, kiterjedt alkalmazáshatóságú gyógyszerek. Gyulladásgátló, allergiaellenes, az immunrendszerre kifejtett hatás és sok más tulajdonságuk miatt használják őket a klinikum szinte minden ágában. A legtöbb esetben a terápiás felhasználás célja egy szerv vagy a szervezet limitált része. Mivel a glükokortikoid-receptor (GR) mindenütt jelen van a szervezetben, szinte lehetetlen elválasztani a kívánt helyi hatást az általános szisztémás hatástól, a jelen esetben a nemkívánatos mellékhatástól. Ez különösen szemészeti alkalmazás esetében áll fenn, ahol a szemcsepp legnagyobb része (mintegy 97 százalék) a könny által történő hígítás és lemosás után az egész testbe eljut, s ott kiváltja a várható mellékhatásokat.

Másrészt a szem esetében még inkább fontos, hogy a tipikus, ismert mellékhatások mellett a kortikoszteroidoknak egyedi, helyi mellékhatásaik is vannak. Elsősorban emelik a belső szemnyomást (IOP) (főleg a szteroidérzékeny betegekben), ami glaukómát okozhat. Egy másik, nagyon fontos mellékhatás a katarakta, amelyet a szteroid reakciója okoz a szemlencse fehérjéivel. Ez a reakció a minden kortikoszteroidban jelen lévő C20-as ketoncsoport és a fehérje amincsoportja között történik, majd ennek átrendeződése után kicsapódik a lencsében.

Ezek a szemészeti mellékhatások jelentkeznek a szteroidok egyéb úton történő alkalmazásakor is, például inhalatív terápia (asztma kezelése), transdermalis alkalmazás során (bőrbetegségek).

A fentiekből következik az új típusú, lágy kortikoszteroidok kifejlesztésének szükségessége.

A lágygyógyszer-módszer alkalmazásakor először az ismert vagy valószínű gyógyszer-metabolizmusokat kell feltérképezni. A természetes kortikoszteroid, a hidrokortizon metabolizmusa során több mint 16 metabolit képződik [13], mind oxidáció, mind redukció eredményeként. A lágy szteroid tervezésekor, az előbb említett okok miatt, az oxidációs folyamatok eredményezte metabolitokat kell vizsgálnunk mint lehetséges alkalmas kiinduló szerkezeteket. A szteroidgyưrú oxidációja különböző analóg metabolitokat eredményez, melyek nem 

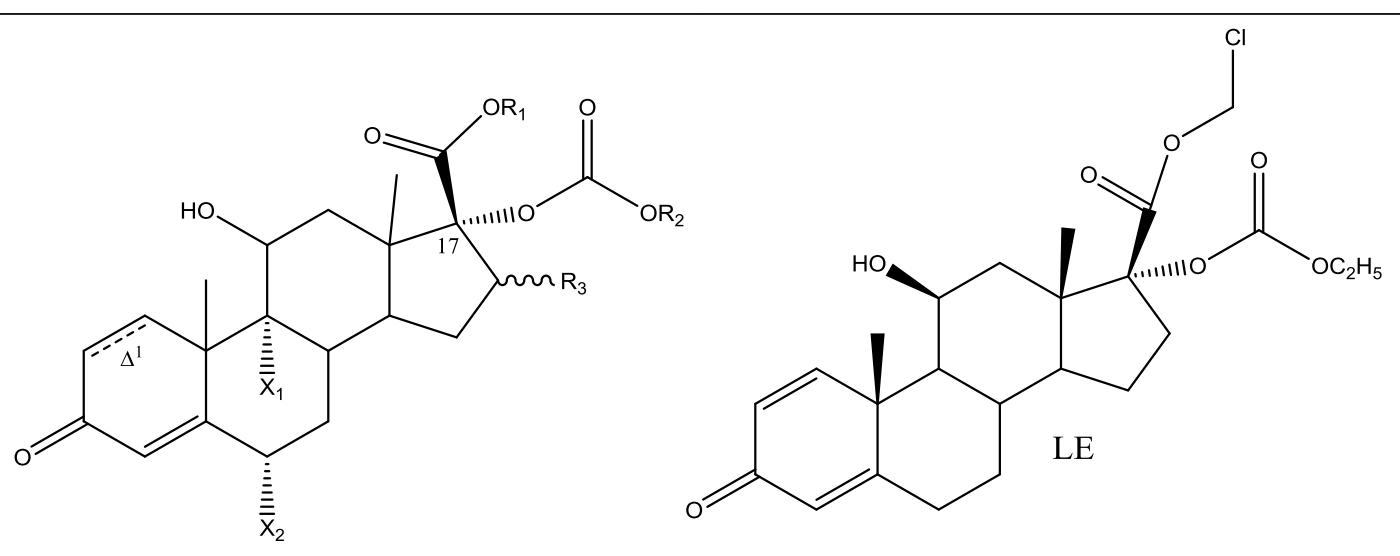

3. ábra

| A 17 -karbonát-17ß-halometil-észter típusú lágy kortikoszteroidok általános képlete. Jobbra a kiválasztott loteprednol-etabonát (LE)

alkalmasak a lágy gyógyszer tervezésére. Figyelmünket a nagyon fontos farmakoforra, a C17-dihidroxi-aceton-oldalláncra fordítottuk. Ennek oxidációja során végtermékként savak képződnek, amelyek közül a kortiensavat választottuk kiinduló anyagnak, ahol a C21 - és C20-keton egy karboxicsoporttá oxidálódott.

Továbbá ennek a megfelelő észterezésével visszaállíthatjuk a volt C21-heteroatomot (kritikus farmakofor) helyettesíthetô pozíciót, például egy halometil-észterrel. Ugyanakkor a $17 \alpha$-hidroxi-csoportot rendszerint elöre észterezik, ezzel jelentősen növelve a kortikoidhatást. A mi esetünkben ezt egy karbonátfunkcióval helyettesítettük, amely sokkal stabilabb, így elkerülhető a vegyes anhidridképződés, ami reakcióképes és toxikus lenne (például kataraktát okozhat). Az így megtervezett lágy kortikoszteroidok általános szerkezete a 3. ábrán látható.

Az itt ábrázolt általános szerkezetben a $17 \alpha$-karbonátés a $17 \beta$-halometil-észter-funkciók újak, eddig nem vol-

1. táblázat | Kortikoszteroidok terápiai indexének összehasonlítása ${ }^{a}$

\begin{tabular}{lcccccc}
\hline Szteroid & $n$ & $\mathrm{ED}_{50}{ }^{\mathrm{b}}$ & Rel. pot. $^{\mathrm{c}}$ & $\mathrm{TD}_{50}{ }^{\mathrm{d}}$ & Rel. pot. $^{\mathrm{e}}$ & $\mathrm{TI}^{\mathrm{f}}$ \\
\hline $\begin{array}{l}\text { Loteprednol-eta- } \\
\text { bonát }(0,1 \%)\end{array}$ & 8 & 178,0 & 0,48 & 10,000 & 0,02 & 24,0 \\
\hline $\begin{array}{l}\text { Hidrokortizon- } \\
\begin{array}{l}17 \alpha \text {-butirát (HB) } \\
(0,1 \%)\end{array}\end{array}$ & 8 & 121,0 & 0,70 & 369 & 0,57 & 1,3 \\
\hline $\begin{array}{l}\text { Betametazon-17 } \alpha- \\
\text { valerát (BV) }\end{array}$ & 8 & 84,8 & 1,00 & 212 & 1,00 & 1,0 \\
$(0,12 \%)$ & & & & & \\
\hline $\begin{array}{l}\text { Klobetazol-17 } \alpha- \\
\text { propionát (KP) } \\
(0,1 \%)\end{array}$ & 8 & 2,9 & 29,70 & 11 & 19,30 & 1,5 \\
\hline
\end{tabular}

aBôr alá helyezett vattagolyómódszer

'Gyulladásgátló hatás ( $\mu \mathrm{g} / \mathrm{vattacsomó)}$

'Relatív gyulladásgátló hatás, betametazonhoz viszonyítva

${ }^{\mathrm{d}}$ Mellékhatás: timolízishatás ( $\mu \mathrm{g} /$ vattacsomó)

'Relatív timolízishatás

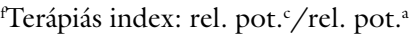

$\mathrm{ED}=$ etiprednol-dikloacetát $; \mathrm{TD}$ = toxikus dózis; $\mathrm{TI}$ = terápiás index tak ismertek a szteroidkémiában. Számos molekulát szintetizáltunk, a megfelelő gyưrúszubsztituensek változtatásával. A kapott lágy kortikoszteroidok meglepóen magas receptorkötődést mutattak [13, 14]. A lágy gyógyszerek sikerében a betervezett hidrolitikus metabolizmus sebessége meghatározó, fontos tulajdonság. A hatás és a metabolizmus egyensúlya alapján további kifejlesztésre a prednizolon sav metabolitjéből $(\Delta$ l-kortiensav, vagy predniensav) származó $17 \alpha$-etilkarbonát-17 $\beta$-klór-metil-észtert választottuk. Hivatalos neve loteprednol-etabonát (LE, klór-metil-17 $\alpha$ etoxikarboniloxi-11-hidroxi-3-oxoandroszta-1,4-dén17ß-karboxilát). Az új, lágy LE drámaian megjavult terápiás indexe az 1. táblázatban látható. Érdekes megjegyezni, hogy a klasszikus kortikoszteroidok - HB, BV és $\mathrm{KP}$ - bár erősen különböző hatással rendelkeznek, a terápiás index értéke mindegyiknél l körül van, az aktivitás és a toxicitás párhuzamosan fut, tehát a hatásosabb szteroid toxikusabb is. Ezzel szemben a LE legalább 20-szor kevesebb mellékhatást mutat. Ez az eredmény világosan illusztrálja a lágygyógyszer-tervezés előnyeit (1. táblázat, 4. ábra).

Az 1980-ban [14] felfedezett LE 1998-ban került az amerikai piacra, először két különböző termékként, az óriás papillás kötőhártya-gyulladás, szezonális allergiás kötőhártya-gyulladás, hályogmütétet követő gyulladás és uveitis kezelésére. Ez az egyetlen kortikoszteroid, melynek használatát az FDA jóváhagyta valamennyi gyulladásos és allergiás szembetegség kezelésére. Sok tanulmány jelent meg azóta, melyek közül csak néhányat emelünk ki, amelyek a loteprednol jó klinikai hatását mutatják be, miközben nem emeli a belső szemnyomást [15], vagy a különösen meggyőző tanulmányt a szaruhártya-átültetés utáni krónikus kezelésről [16]. Az általánosan elfogadott kezelés a prednizolon-acetát, amely a betegeknél a belső szemnyomás jelentős emelkedését okozta, főleg a szteroidérzékeny személyeknél. A kezelőorvos egyszerúen helyettesítette a prednizolont LE-vel, amely minden esetben jelentősen visszafordította és két hónap alatt minden esetben normalizálta az emelkedett szemnyomást, s ami a legfontosabb, anélkül hogy egyetlen allográf kilökő- 


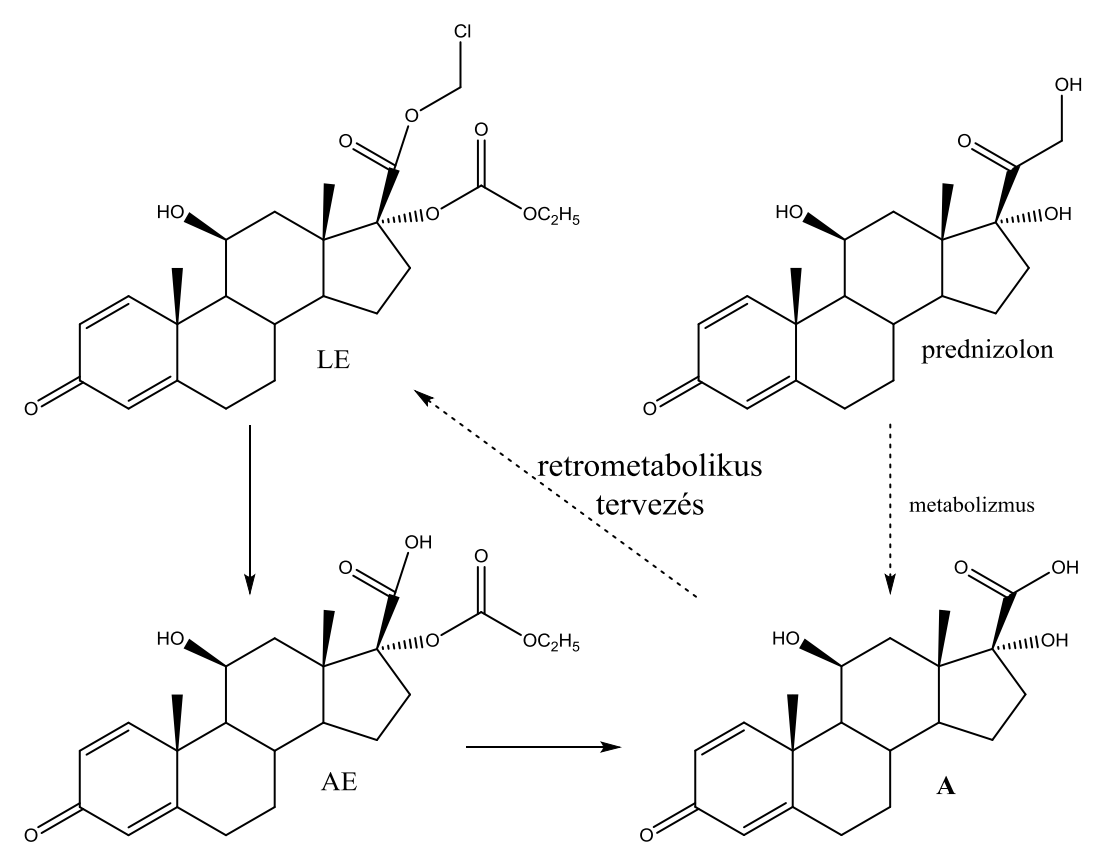

4. ábra $\mid \begin{aligned} & \text { A loteprednol-etabonát }(\mathrm{LE}) \text { formális tervezése a prednizolon metabolitjából és a tervezett, aktuális metabolizmus } \\ & \mathrm{P}=\text { prednizolon; } \mathrm{A}=\Delta \mathrm{l} \text {-kortiensav; } \mathrm{AE}=\Delta \mathrm{l} \text {-kortiensav-etil-karbonát }\end{aligned}$

dött volna. Több újabb hatékony LE-kiszerelést (gél, kenőcs) hagyott jóvá az amerikai hatóság (FDA) [17]. Legújabban egy 0,38\%-os gélt használtak kataraktamütétet követően [18]. A gyulladás és fájdalom 14 napi sikeres kezelése után egyetlen betegnél sem találtak jelentôs szemnyomás-emelkedést.

Egy nagyobb lélegzetü összefoglaló cikk jelent meg 2018-ban, amelynek címe „Az első retrometabolikus elvek alapján tervezett lágy kortikoszteroid 20 év klinikai tapasztalatairól” [19]. A szerzők 32 különböző klinikai vizsgálatot soroltak fel. Az eddig jóváhagyott négy felhasználás mellett újabb klinikai felhasználást is leírtak, mint szemhéjgyulladás, szárazszem-betegség (keratoconjunctivitis sicca), Meibom-mirigy-diszfunkció, LASIK (laser-assisted in situ keratomileusis) utáni fájdalom és gyulladás stb. (Majd' 95 millió felhasználóról tudnak.) A végkövetkeztetés, hogy a LE nagyon jó hatású, de sokkal kevesebb mellékhatással bíró szteroid, minden mással összehasonlítva. Jelenleg négy amerikai gyógyszervállalat összesen kilenc különböző termékének hatóanyaga a loteprednol-etabonát.

A LE szemészeti alkalmazása nagyon sikeres, de számos előnyös tulajdonsága miatt használata egyéb klinikai területen is ígéretes. A mellékhatások hiánya fontos például a bőrgyógyászati alkalmazásnál. Egy különleges tulajdonsága itt még fontosabbá teszi. A jelenleg forgalomban lévő kortikoszteroidokkal ellentétben a LE jól kötődik nemcsak a glükokortikoid-receptorhoz (GR), hanem a CBG (corticosteroid-binding globulin), transzkortin nevú természetes hordozó globulinhoz is, amely a szervezetben a hidrokortizont juttatja el a sejtekbe. Érdekes módon a LE inaktív metabolitja, a $\Delta \mathrm{l}$-kortiensav
(CA) is jól kötődik a transzkortinhoz. Így a LE és a CA keverékének jelenlétében az inaktív CA kompetitív módon megakadályozza a LE aktív elszállítását, így helyileg nagyobb koncentrációban marad a LE. Ennek eredményeként a LE + CA kombináció hatásosabb, mint a LE önmagában ugyanolyan koncentrációban [20]. Továbbmenve azt találtuk, hogy a leggyakrabban használt, természetes hidrokortizon helyi hatása ugyanilyen elvek alapján jelentősen megnövelhető, ha 1 : 1 arányban kevert $\Delta \mathrm{l}$-kortiensav-keveréket használunk [21].

Sikerült tisztázni, melyik észteráz hidrolizálja a LE-t. Azt találtuk, hogy a HDL-hez (high-density lipoprotein) kapcsolódó paraoxonáz-1 hidrolizálja a klór-metil-észtert a LE-ben [22].

Ennek általános hatásbeli és megoszlási következményei is vannak, mert a paraoxonáz-1 koncentrációja különböző a test különböző részeiben.

A $\Delta \mathrm{l}$-kortiensav, a prednizolon inaktív metabolitja, a LE-tervezési kiinduló molekula, egy más típusú lágygyógyszer-csoportot is eredményezett. Minden aktív kortikoszteroid fontos farmakoforja a C21-hez kötődő heteroatom $(\mathrm{OH}, \mathrm{Cl}$ vagy $\mathrm{F})$, míg a $\mathrm{LE}$ esetében ezt a feladatot az izoszterikus-izoelektronikus klór-metil-észter látja el. Ezek mind a C17 $\beta$-helyzetű oldalláncában vannak. Meglepő eredményünk, hogy a C17 $\alpha$-láncában is lehet farmakofort létrehozni. A $17 \alpha$-diklór-acetátban, szterikus kölcsönhatások miatt és megfelelő elfordítással, az egyik klóratom mindig pontosan a kívánt (eredetileg C21-heteroatom) farmakofori helyet foglalja el, így a C17ß-karbonsav észterezéséhez egy egyszerü alkilcsoport is elegendő, hogy nagyon jó aktivitású lágy gyógyszert kapjunk $[23,24]$. Az így kapott etiprednol-diklo- 


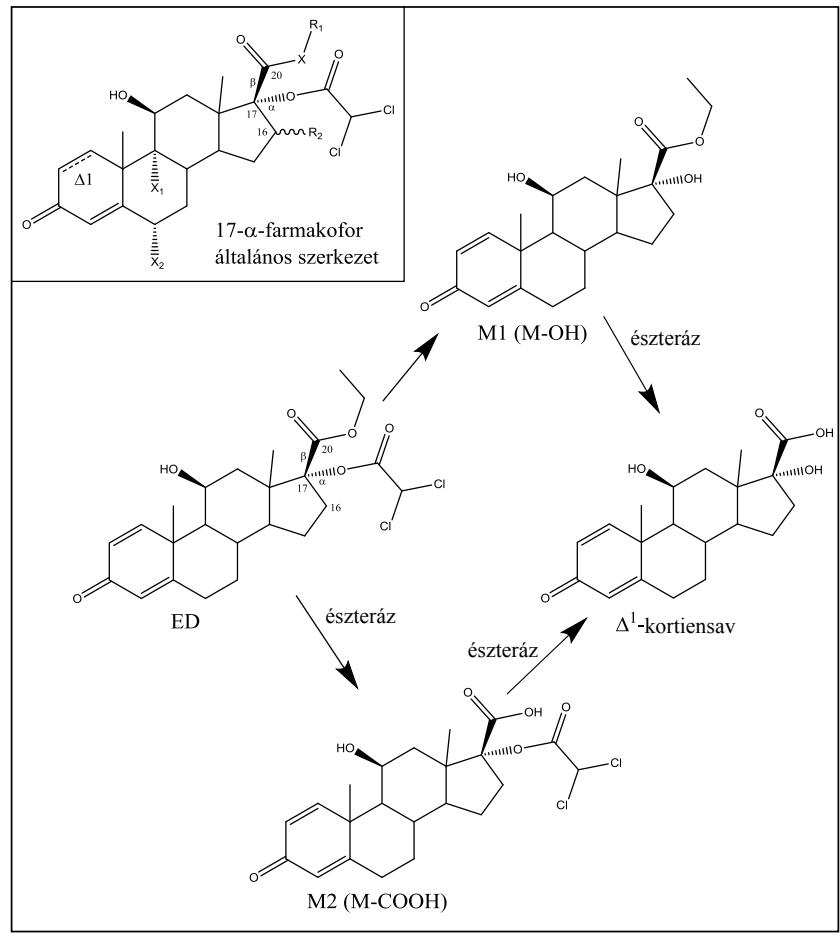

5. ábra

A $17 \alpha$-oldalláncban lévő farmakofor vegyületek általános képlete, R1-alkil, X- O vagy S, R2 - H, -OH vagy - $\mathrm{CH} 3$, Xl és X2 $\mathrm{H}$, - F vagy $\mathrm{Cl}$. Etiprednol-dikloacetát $(\mathrm{ED})$ és a hidrolitikus metabolizmus két lehetséges útja. $\mathrm{M}_{1}(\mathrm{M}-\mathrm{OH})$ a fó metabolit emberben, $\mathrm{M}_{2}(\mathrm{M}-\mathrm{COOH})$ patkányban

acetát (ED) szintén klinikai fejlesztésre került, elsősorban rhinitis kezelésére. Sikeresen eljutott a klinikai III. fázisig. Az ED valamivel aktívabb, mint a LE, és tekintve, hogy egy diészter, 'lágyabb' a LE-nál. Terápiás indexe is jobb (TI 30). Ez az első eset, hogy a farmakofor egy kortikoszteroidban a $17 \alpha$-pozícióban van. Bár mindkét észter enzimatikus hidrolízisen megy át, a monoészter közti termék képződése fajfüggő: patkányban az etil-észter hidrolizálódik, míg nagyon meglepő módon emberben a $17 \alpha$-diklór-acetát tûnik el először.

Kiderült, hogy az ED hidrolíziséért szintén a paraoxonáz-1 felelős [22]. Az 5. ábra bemutatja a 17 $\alpha$-diklóracetil típusú farmakoforalapú lágy kortikoszteroidokat (ED, etiprednol-dikloacetát, Rl -C2H5, X -O, R2, Xl and X2, all -H). A kiválasztott ED hidrolitikus metabolizmusának két lehetősége is látható.

$\mathrm{Ez}$ a váratlan eredmény, hogy egy kortikoszteroid $17 \alpha$-észter-funkciója hidrolizál (példa nélküli a kortikoszteroidoknál), adta az ötletet, hogy új, nagyon hatásos analógot tervezzünk, kiindulva a legaktívabb, számos terápiás területen használt flutikazon-propionátból. Formailag kicseréljük a propionátcsoportot a flutikazonpropionátban diklór-acetátra [25]. A lágy flutikazondiklór-acetát ( $\mathrm{Rl}-\mathrm{CH} 2 \mathrm{~F}, \mathrm{R} 2 \alpha-\mathrm{CH} 3, \mathrm{X}-\mathrm{S}, \mathrm{Z}-\beta-\mathrm{CHOH}$, $\mathrm{Xl}-\mathrm{F}, \mathrm{X} 2-\mathrm{F}, \Delta \mathrm{l})$ ugyanolyan aktív, mint a flutikazon, de emberi plazmában tartva egy éjszakán át, elveszti hatásának 99\%-át, tehát nagyon lágy. Ez nagyon ígéretes új gyógyszerjelölt, tekintve, hogy a flutikazon a legaktívabb, ugyanakkor a legtoxikusabb kortikoszteroid (6. ábra).

\section{Lágy antikolinerg anyagok}

A kortikoszteroid-receptorokhoz hasonlóan a kolinerg receptorok is mindenütt jelen vannak a szervezetben. Ezeknek az acetil-kolin aktivitását közvetítő tipikus G-proteinhez kapcsolt metabotrop receptoroknak öt altípusuk van $\left(\mathrm{M}_{1}-\mathrm{M}_{5}\right)$, de tekintve, hogy nem ismert sze-

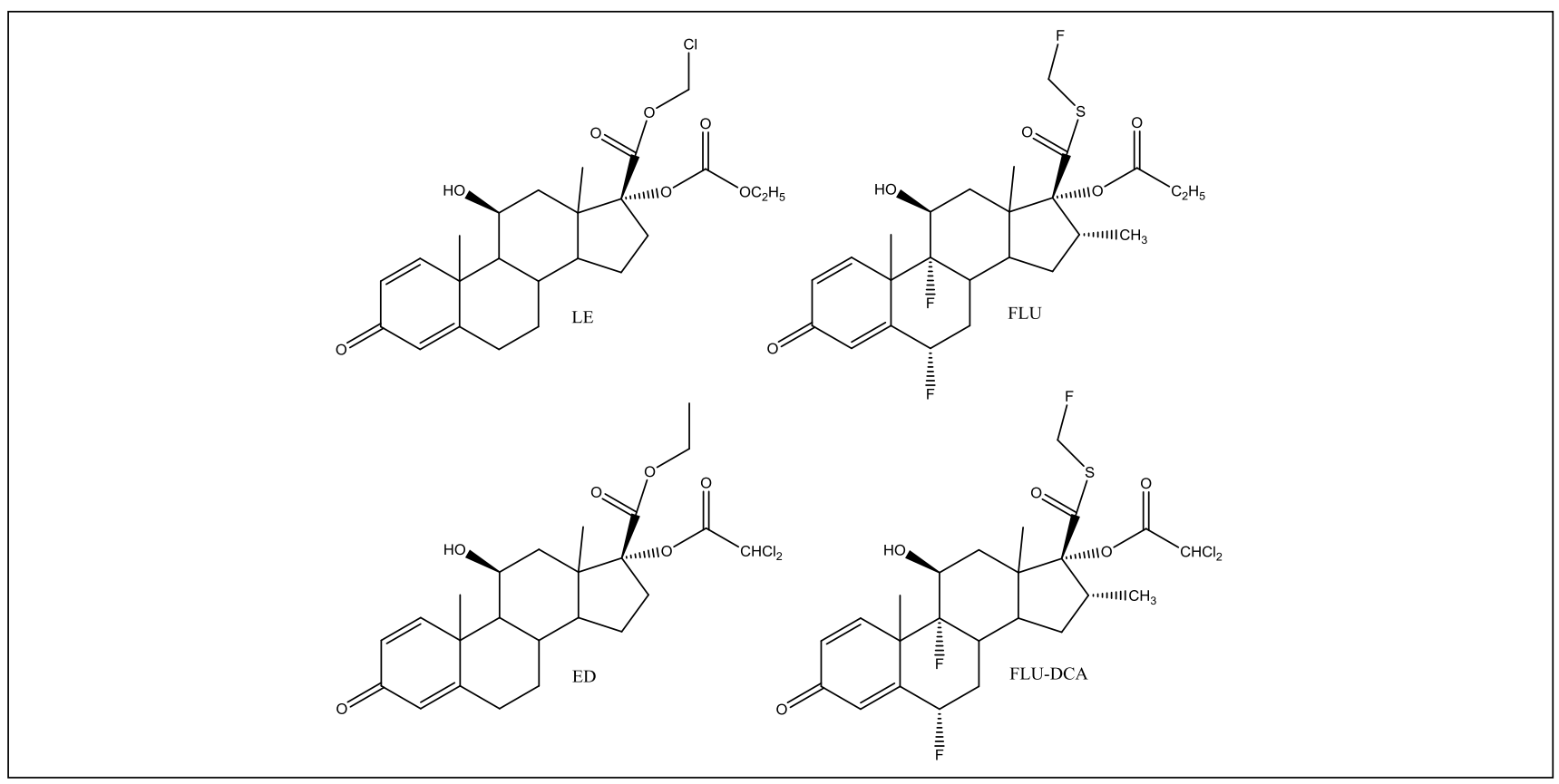


letív agonista vagy antagonista molekula, nagyon nehéz elválasztani egy kívánt hatást a mellékhatásoktól.

$\mathrm{Az}$ antikolinerg anyagoknak sok terápiás felhasználásuk van, mint az asztma, COPD $\left(\mathrm{M}_{3}\right)$, gyomorfekély $\left(M_{1}\right)$, Alzheimer $\left(M_{2}\right)$ - és Parkinson $\left(M_{4}\right)$-kór, tengeribetegség, pupillatágítás, bélmozgás, helyi váladékképzés (izzadtság $\left[\mathrm{M}_{3}\right]$, nyál) gátlása, hólyagfunkció $\left(\mathrm{M}_{2}, \mathrm{M}_{3}\right)$ stb. A szelektivitás hiányában sok hatás mellékhatásként jelentkezik (száraz száj, fényérzékenység, hólyag- és bélmozgási problémák, arrhythmia, hallucináció, dementia stb.), ami erősen korlátozza felhasználásukat. Helyi váladékképzés-gátló hatásukat nagyon régóta próbálják a kóros izzadás (hyperhidrosis) kezelésére kihasználni. Jól ismert, hogy a szkopolamin vagy atropin- és kvaternerammónium-származékaik gátolják az izzadást, de számos mellékhatásuk miatt nem engedélyezhetők. A megoldást egy, csak helyileg ható antikolinerg szer jelentené. Kezdve 1980-tól [11], ismert antikolinerg molekulákból kiindulva, számos lágy antikolinerg anyagot terveztünk és tanulmányoztunk. A lágygyógyszer-tervezés különbö- ző módszereit alkalmaztuk. Először a lágyanalóg-módszert alkalmaztuk, az elfogadott tercier vagy kvaterner ammónium-észter kolinerg farmakofort próbáltuk 'lágyítani’. Az acetil-kolin (AK) szerkezete alapján az általánosan elfogadott antikolinerg farmakofor két vagy három szénatommal választja el az észter-oxigént és a kvaterner ammónium-nitrogént. Ismerve, hogy az acetil-norkolin (ANK) 5000-szer kisebb aktivású, mint az acetil-kolin, senki sem próbált ebből származó, csak egy szénatommal elválasztott antikolinergeket készíteni és kipróbálni. A lágy gyógyszer elve alapján az első próbálkozások ilyen típusú származékokat céloztak meg, több különböző lágy molekulát szintetizáltunk. Meglepő módon szinte mind olyan erős antikolinerg aktivitást mutatott, mint a 'kemény' analógok. Hidrolízis eredményeképpen ez az új farmakofor három komponensre esik szét, tehát lágy (7/A ábra). A probléma az volt, hogy ezek az acetil-norkolinon alapuló farmakoforok csak aránylag lassú, kémiai és nem enzimatikus hidrolízisre
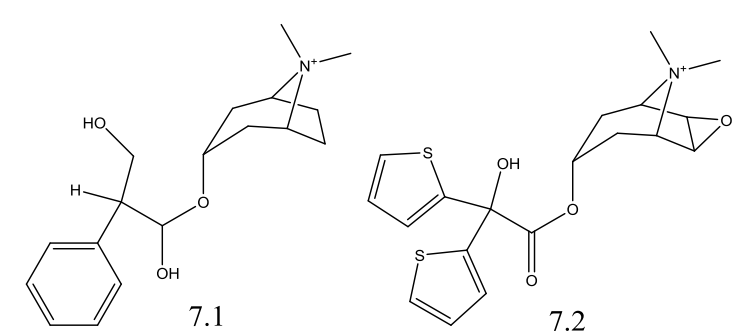

7.2
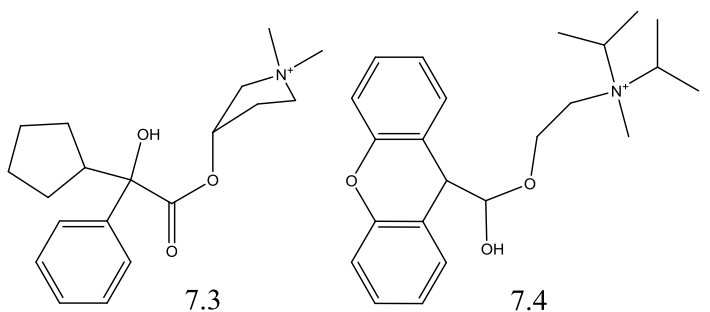

7.4

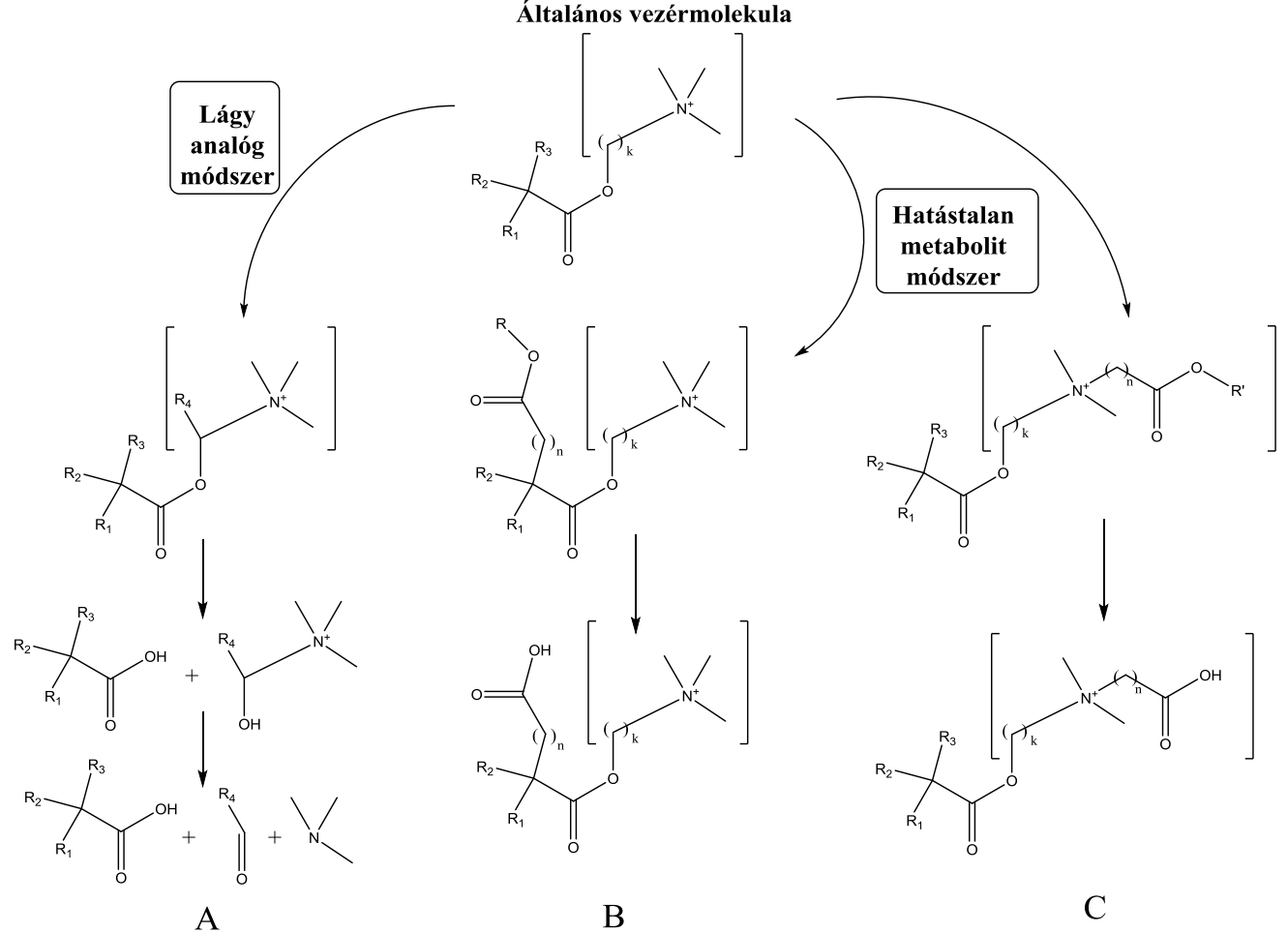

7. ábra

A lágy antikolinerg anyagok tervezésének különböző módjai. A felső sorban az ismert kiinduló antikolinergek szerkezete: 7.1 metil-atropin, 7.2. tiotropium, 7.3. glikopirrolát, 7.4 propantelin. A) Lágy analógok tervezése; csak egy szénatom választja el az észter-oxigént és a kvaterner nitrogént, mint az acetil-norkolinban. R1-, R2-, R3-cikloalkil, fenil, CH2OH, H, R4 H vagy alkil. Hidrolízissel szétesik a molekula egy sav, egy aldehid és egy tercier aminra. B) Inaktívmetabolit-módszer; a beépített lágy rész a farmakofort befolyásolja, malonsav- vagy szukcinsav-diészterek $\mathrm{k}-(\mathrm{CH} 2) \mathrm{n}$, n- 2,3., C) Inaktívmetabolit-módszer; a lágy rész távol a farmakofortól, a molekula végén található, k - mint fent, a - $\mathrm{CH} 2-, \mathrm{R}$ - $\mathrm{CH} 3, \mathrm{C} 2 \mathrm{H} 5$ 
érzékenyek, és bár helyi alkalmazáskor hatnak, a szisztémás hatások így nem kerülhetők el [26].

Ezután a 'hatástalanmetabolit-módszert' alkalmaztuk különböző ismert antikolinerg molekulákból kiindulva (metil-atropin, metszkopolamin stb.) - a kvaterner származékokat választottuk, elkerülve így az esetleges központi idegrendszeri hatást, hiszen a pozitív töltés miatt ezek nem tudnak áthatolni a vér-agy gáton. A hidroximetil-csoport a fenil-ecetsav részben $(7 / B$ ábra) jó 'lágyítási' célpontnak ígérkezett, ez feltételezhetóen savvá oxidálódhatna, ami a tervezési 'hatástalan metabolit' lenne (megjegyzendő, hogy ez egy feltételezett metabolit, nem sikerült kimutatni az atropin metabolizmusa során, de a lágygyógyszer-tervezés ilyen lehetséges metabolitokat is használhat). Ennek a savnak alkil-észterei a lágy antikolinergikumok. Lényegében ezek egy malonsav diészterei, vagy még egy szénnel megtoldva, szukcinsav diészterei. A legtöbb új molekula - elsősorban a szukcinsavszármazékok - nem bizonyult megfelelően aktív anyagnak [27]. Az atropinból származó fenil-malonsavanalóg viszont megközelítette az atropin hatáserősségét (pA2 7,85 vs. 8,29). Ez kifejlesztésre került, tematropium néven. Világossá vált viszont, hogy az antikolinerg farmakofor közvetlen közelébe bevitt észterfunkció, bár sikeresen 'lágyította' a molekulát, nem biztosítja a megfelelő izoelektronikus környezetet. A klinikai II. fázis után ennek további fejlesztése leállt, ugyanis új, hatásosabb származékokat találtunk, a hatástalanmetabolitmódszer egy új változatát használva.

A lágygyógyszer-tervezésnek két formailag lényegesen különböző stratégiája létezik: a) a betervezett metabolizmus a farmakofort megsemmisíti, ilyen a loteprednoletabonát és a fenti antikolinerg analógok, b) a betervezett metabolizmus a farmakofortól távol van, de a metabolizmus hatástalanítja a molekulát, a metabolit hatástalan, és gyorsan eltávozik a szervezetből. Ezzel a módszerrel nagyon sikeresen fejlesztettek lágy, ultragyors hatású béta-blokkolókat (mint az ezmolol vagy a landiolol).

Az új stratégia kiinduló anyaga a glikopirrolát volt $[28,29]$. A metabolizmus tervezése során a dimetil-kvaternerammóniumsóból az egyik metilcsoportot behelyettesítjük etoxikarbonil-metil-csoporttal (7/C ábra). $\mathrm{Az}$ eredeti ammónium-észter farmakofor ugyanaz maradt, de az újonnan létrehozott alkil-észter könnyen hidrolizál enzimatikusan. A leírt különböző, lágy tervezés felhasználásával szintetizált és tanulmányozott antikolinerg származékokat, összesen 76 molekulát, sikeresen egyesítettük egy hatás-szerkezet összefüggésben, amelyben a molekula térfogata a legfontosabb meghatározója a hatásnak. Az összefüggés egy bilineáris, biexponenciális egyenlet [30].

Az új, glikopirrolátból tervezett lágy molekulában három optikai aktív centrum van. Az így létrehozott mind a nyolc tiszta izomert tanulmányoztuk, meghatároztuk a muszkarinreceptorok kötődését [31, 32]. A fó cél az $M_{3}$ receptor-kötődés optimalizálása volt. A leghatásosabb

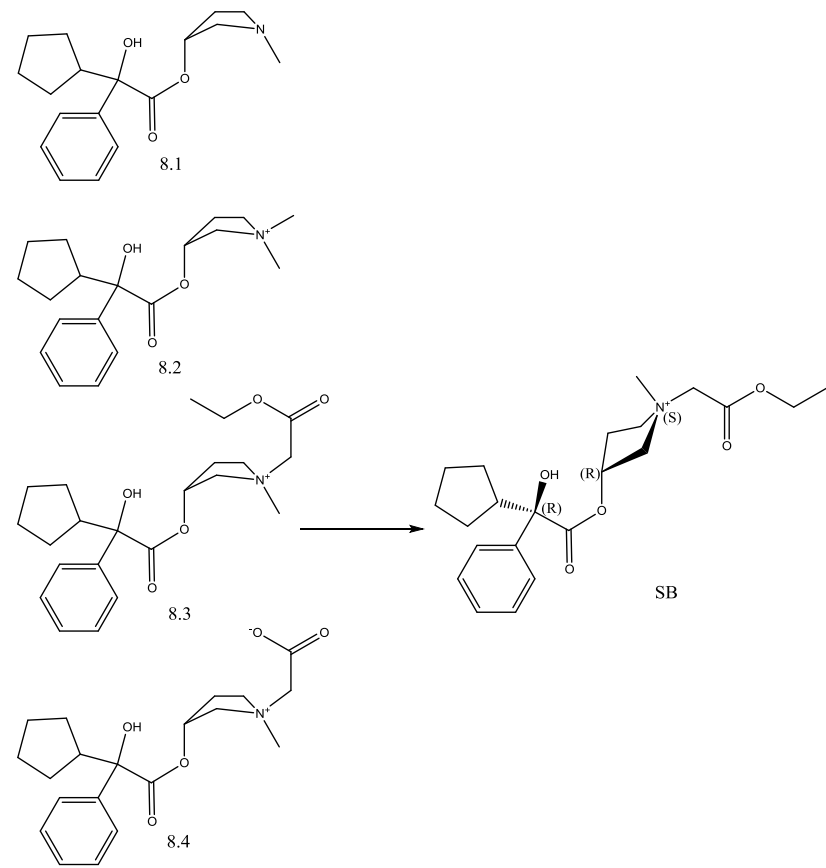

8. ábra

A sofpironium bromide (SB) tervezése és metabolizmusa. 8.1 A glikopirrolát tercier analógja. 8.2 Glikopirrolát. 8.3. A lágy optikai izomerek keveréke, a 8.1 és az etil-bróm-acetát reakciójából képződik. SB- a kiválasztott és kifejlesztett optikai izomer

izomer a 2R,3'R, az Nl mindkét izomerje azonos hatású volt, tehát azokat nem kellett elválasztani. A végtermék l: 3 arányban tartalmazza a két Nl-es izomert. Ez az új, lágy antikolinerg a hyperhidrosis (egy kielégítetlen szükséglet) kezelésére lett először kifejlesztve ( 8 . ábra).

Hivatalos (USAN) neve sofpironium bromide (SB) (kémiailag (2R,3'R)3-(2-ciklopentil-2-fenil-2-hidroxiacetoxi)-1-(etoxikarboniloxi)-1-metilpirrolidinium bromide) $[33,34]$. Agresszív fejlesztési program eredményeképpen két II/b fázis statisztikailag jelentős eredményt hozott minden elsődleges és másodlagos klinikai végpontban. Japánban is fejlesztésre került, a japán vállalat még gyorsabban fejlesztette, 2019. júniusban sikeresen befejezték a karcinogenitási vizsgálatokat és a III. klinikai fázist is, így a végső dokumentumok készülnek a forgalomba hozatal engedélyezéséhez. Az anyag topikális használatra készült, jó és hosszan tartó hatása van, nincs viszont mellékhatása, tekintve, hogy emberi plazmában a felezési ideje csak $t / 2=11,3$ perc. Érdekes, hogy ezt az anyagot is a paraoxonáz-l hidrolizálja; az egyetlen metabolit a 'zwitterion' (ikerion) [35], amely egy nagyságrenddel gyengébb antikolinerg, és nagyon gyorsan kiürül a szervezetból.

A sofpironium bromide biztonságos lágy antikolinerg, mely valószínúleg számos egyéb terápiás területen is alkalmazható lesz, ahol az antikolinerg hatás kihasználható. Tulajdonságai alapján elsősorban a COPD és a patológiás nyáltermelődés kezelésére ajánlott.

Végül e rövid áttekintés után álljon itt néhány általános megjegyzés a retrometabolikus és különösképpen a lágygyógyszer-tervezés alkalmazásáról. Világossá vált, 


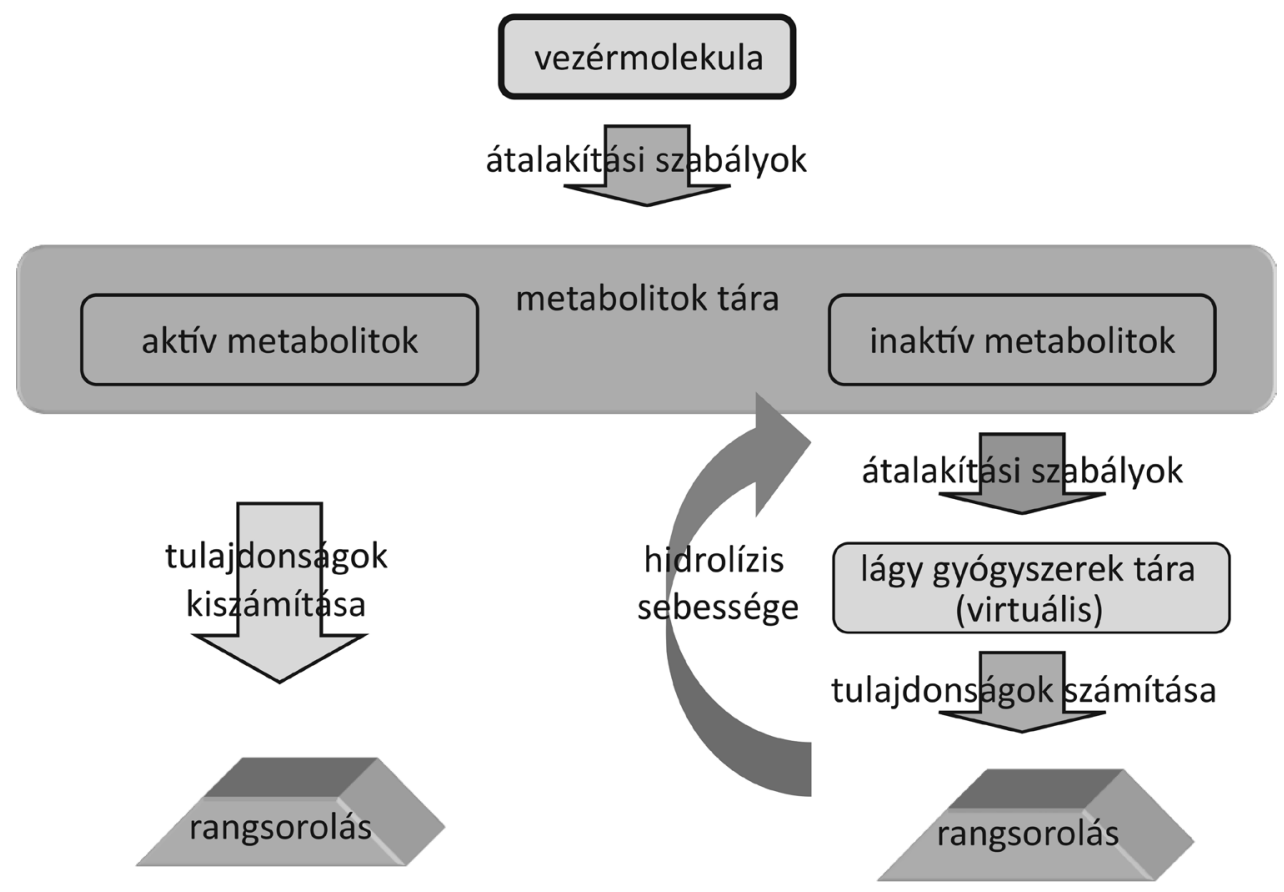

9. ábra

| A lágygyógyszer-tervezés számítógépes szakértői rendszerének vázlatos bemutatása

hogy egy általános, logikus tervezésimódszer-rendszerrôl beszélünk. Az új gyógyszerfejlesztés szinte minden ágában sikeresen lehet alkalmazni, és valóban, egyre több munka jelenik meg alkalmazásáról és klinikai sikerekről. Itt csak annyit szeretnénk hozzátenni, hogy tekintve, hogy a kiinduló metabolitok identifikálása és kiválasztása megalapozott és kidolgozott módszerek alapján történik, ezeket könnyen lehet egy számítógépes szakértői rendszerbe foglalni [36]. Tehát egy aktív anyagból kiindulva, a logikus átalakítási szabályok (a molekula oxidálható szerkezeti elemeit a program felismeri, például a -CH-OH oxidálódna -CHO-, majd -COOHcsoporttá) automatikusan létrehozzák a lehetséges metabolitok teljes tárát. Az elvileg oxidált metabolitokból lágy gyógyszereket (például észtereket) tervez a számítógép, ismét a betáplált átalakítási szabályoknak megfelelően. Ezek izoszterikus-izoelektronikus tulajdonságait (a molekula alakja, térfogata, felület, töltéseloszlás, vízoldhatóság, megoszlási hányados, polarizálhatóság stb.) kvantumkémiai módszerrel kiszámíthatjuk, ugyancsak a hidrolitikus metabolizmus sebességét emberi plazmában [37]. E számított tulajdonságok arányos kombinációja számszerű rangot eredményez, melynek alapján a legígéretesebb (izoszterikus/izoelektronikus közelítés a vezérmolekulához) lágy gyógyszerek sorrendje kialakul. Így az ígéretes rendszerek még azelőtt kiértékelhetők, hogy a kísérleti és kipróbálási programot elindítanánk. A folyamatot vázlatosan a 9. ábra mutatja be.

Bár nem lágy gyógyszer, de a kiszerelés fontosságára hívja fel a figyelmet, és így a jelen témához tartozva említést érdemel a tavaly az Európai Unióban s az idén az Egyesült Államokban és sok más országban jóváhagyott és piacra került Mavenclad (2-klór-2'-dezoxi-adenozin, kladribin HP $\beta \mathrm{CD}$ komplex-komplex [38]), a sclerosis multiplex nagyon sikeres rövid tartamú, orális kezelésének új gyógyszere. A preklinikai állati farmakokinetikai, majd az első emberi klinikai vizsgálatokat a budapesti Gyógyszerkutató Intézetben (GYKI) végeztük.

Anyagi támogatás: A szerző anyagi támogatásban nem részesült.

A szerző a cikk végleges változatát elolvasta és jóváhagyta.

Érdekeltségek: A szerzőnek nincsenek érdekeltségei.

\section{Irodalom}

[1] Bodor N, Buchwald P. Retrometabolic drug design and targeting. John Wiley \& Sons, New York, NY, 2012. ISBN 978-0470-94945-0.

[2] Bodor N, Buchwald P. Retrometabolic drug design and targeting. In: Abraham DJ, Rotella DP. (eds.) Burger's medicinal chemistry, drug discovery and development. Vol. 2: Discovering lead molecules. 7th edn. Wiley, New York, NY, 2010; chapter 3.

[3] Bodor N, Shek E, Higuchi T. Delivery of a quaternary pyridinium salt across the blood-brain barrier by its dihydropyridine derivative. Science 1975; 190: 155-156.

[4] Bodor N, Farag HH, Brewster M 3rd. Site-specific, sustained release of drugs to the brain. Science 1981; 214: 1370-1372.

[5] Bodor N, Simpkins JW. Redox delivery system for brain-specific, sustained release of dopamine. Science 1983; 221: 65-67.

[6] Bodor N, Prokai L, Wu WM, et al. A strategy for delivering peptides into the central nervous system by sequential metabolism. Science 1992; 257: 1698-1700. 
[7] Bodor N, Buchwald P. Brain-targeted delivery of estradiol: therapeutic potential and results obtained with a chemical delivery system approach. Am J Drug Deliv. 2006; 4: 161-175.

[8] Bodor N. Novel approaches for the design of membrane transport properties of drugs. In: Roche EB. (ed.) Design of biopharmaceutical properties through prodrugs and analogs. American Pharmaceutical Association, Washington, DC, 1977; pp. 98 135 .

[9] Bodor N, Kaminski JJ, Selk S. Soft drugs 1. Labile quaternary ammonium salts as soft antimicrobials. J Med Chem. 1980; 23: $469-474$.

[10] Bodor N, Kaminski JJ. Soft drugs 2. Soft alkylating compounds as potential antitumor agents. J Med Chem. 1980; 23: 566-569.

[11] Bodor N, Woods R, Raper C, et al. Soft drugs 3. A new class of soft anticholinergic agents. J Med Chem. 1980; 23: 474-480.

[12] Buchwald P, Bodor N. Recent advances in the design and development of soft drugs. Pharmazie 2014; 69: 403-413.

[13] Bodor N, Buchwald P. Corticosteroid design for the treatment of asthma: structural insights and the therapeutic potential of soft corticosteroids. Curr Pharm Des. 2006; 12: 3241-3260.

[14] Bodor N. Soft steroids having anti-inflammatory activity. Belg Patent BE No.: 889,563 (Cl. CO7J), November 3, 1981; US Patent No.: 4,996,335, February 26, 1991.

[15] Sheppard JD, Comstock TL, Cavet ME. Impact of the topical ophthalmic corticosteroid loteprednol etabonate on intraocular pressure. Adv Ther. 2016; 33: 532-552.

[16] Holland EJ, Djalilian AR, Sanderson JP. Attenuation of ocular hypertension with the use topical loteprednol etabonate $0.5 \%$ in steroid responders after corneal transplantation. Cornea 2009; 28: 1139-1143.

[17] Price M, Feng M, Scanameo A, et al. Loteprednol etabonate $0.5 \%$ gel vs. prednisolone acetate $1 \%$ solution after Descemet membrane endothelial keratoplasty: prospective randomized trial. Cornea 2015; 34: 853-858.

[18] Fong R, Cavet ME, DeCory HH, et al. Loteprednol etabonate (submicron) ophthalmic gel $0.38 \%$ dosed three times daily following cataract surgery: integrated analysis of two Phase III clinical studies. Clin Ophthalmol. 2019; 13:1427-1438.

[19] Comstock TL, Sheppard JD. Loteprednol etabonate for inflammatory conditions of the anterior segment of the eye: twenty years of clinical experience with a retrometabolically designed corticosteroid. Expert Opin Pharmacother. 2018; 19: 337-353.

[20] Wu WM, Bodor ET, Howes J, et al. The effects of $\Delta^{1}$-cortienic acid on skin blanching, pharmacokinetics and stability of loteprednol etabonate. Pharmazie 2012; 67: 406-410.

[21] Bodor ET, Wu WM, Chandran R, et al. Enhanced activity of topical hydrocortisone by competitive binding of corticosteroidbinding globulin. J Pharm Sci. 2016; 105: 2873-2878.

[22] Samir A, Bodor N, Imai T. Identification of esterase involved in the metabolism of two corticosteroid soft drugs. Biochem Pharmacol. 2017; 127: 82-89.

[23] Kurucz I, Tóth S, Németh K, et al. Potency and specificity of the pharmacological action of a new antiasthmatic, topically administered soft steroid, etiprednol dicloacetate (BNP-166). J Pharmacol Exp Ther. 2003; 307: 83-92.
[24] Bodor N. Androstene derivatives. US Patent No.: 5,981,517, November 9, 1999.

[25] Bodor N, Zubovics Z, Kurucz I, et al. Potent analogues of etiprednol dicloacetate, a second generation of soft corticosteroids. J Pharm Pharmacol. 2017; 69: 1745-1753.

[26] Brouillette G, Kawamura M, Kumar GN, et al. Soft drugs 21. Design and evaluation of soft analogs of propantheline. J Pharm Sci. 1996; 85: 619-623.

[27] Kumar GN, Bodor N. Soft anticholinergics. Curr Med Chem. 1996; 3: 23-36.

[28] Ji F, Wu WM, Bodor N. Studies on a soft glycopyrrolate analog, SG-1. Pharmazie 2002; 57: 138-141.

[29] Huang F, Browne CE, Wu WM, et al. Design, pharmacokinetic and pharmacodynamic evaluation of a new class of soft anticholinergics. Pharm Res. 2003; 20: 1681-1689.

[30] Buchwald P, Bodor N. Soft quaternary anticholinergics: comprehensive quantitative structure-activity relationship (QSAR) with a linearized biexponential (LinBiExp) model. J Med Chem. 2006; 49: 883-891.

[31] Tóth-Sarudi E, Tóth G, Pallagi I, et al. Preparation and biological effects of pure stereoisomeric novel soft anticholinergics. Pharamazie 2006; 61: 90-96.

[32] Wu WM, Wu J, Mori N, et al. Stereoisomers of N-substituted soft anticholinergics and their zwitterionic metabolite based on glycopyrrolate - syntheses and pharmacological evaluations. Pharmazie 2008; 63: 200-209.

[33] Bodor NS. Soft anticholinergic esters. US Patent No.: 7,399,861 B2, July 15, 2008.

[34] Bodor N, Angulo D. Method of dosing and using soft anticholinergic esters. US Patent No.: 9,492,429 B2, November 15, 2016.

[35] Samir A, Ohura K, Bodor N, et al. Identification of major esterase involved in hydrolysis of soft anticholinergic (2R3'R-SGM) designed from glycopyrrolate in human and rat tissues. J Pharm Sci. 2019; 108: 2791-2797.

[36] Bodor N, Buchwald P, Huang MJ. Computer-assisted design of new drugs based on retrometabolic concepts. SAR QSAR Environ Res. 1998; 8: 41-92.

[37] Buchwald P, Bodor N. Quantitative structure-metabolism relationships: steric and nonsteric effects in the enzymatic hydrolysis of noncongener carboxylic esters. J Med Chem. 1999; 42: $5160-5168$.

[38] Bodor NS, Dandiker Y. Oral formulations of cladribine. US Patent No.: 8,785,415 B2, July 22, 2014; EP 2,272,503 B1, March 20, 2013.

(Nicholas Bodor dr., University of Florida, Gainesville, Fl és Bodor Laboratories, Inc., Miami, Fl, Amerikai Egyesült Államok, 4400 Biscayne Blvd., Suite 980, Miami, Florida 33137 e-mail: nsbodor@bodorlabs.com) 